\title{
Anais Nin: An Incest Between a Father and a Daughter
}

\author{
Michelle Morin-Bompart \\ Department of Psychiatry, IMM, University of Paris V, Paris, France
}

Email address:

michelle.morin75@orange.fr

\section{To cite this article:}

Michelle Morin-Bompart. Anais Nin: An Incest Between a Father and a Daughter. American Journal of Psychiatry and Neuroscience. Vol. 7, No. 3, 2019, pp. 69-73. doi: 10.11648/j.ajpn.20190703.13

Received: August 7, 2019; Accepted: September 4, 2019; Published: September 19, 2019

\begin{abstract}
In 1933, Anais Nin thirty years old, meets again with her beloved father, the pianist and composer Joachin Nin. She did not see him since the age of eleven when he left his family for a mistress. She then started to write a diary. I want to show that you can make links and interpret the material and associations of her diary like the material of a psychoanalysis or a psychotherapy. When they meet again, he behaves like an incestual father telling her his love affairs and his sexual life with her mother. Then he relates to her an incestuous dream with her and acts like a lover until the consummate incest. She seems to consent but feels guilty, between fear and desire, and disgust. She will complain of intense heart beats, death anxiety and loss of joy. Through her Journal of Incest (1932-1934) and her Youth Journal (1914-1919), I will try to understand how such an incest can happen. The father is an incestuous father who has no taboo of the incest, does not recognize the difference between generations, does not respect the body intimacy of his daughter and treat her like a narcissistic object. He fluctuates between psychosis without symptoms and narcissistic perversion. Anais has a hysterical personality, with separation anxiety, psychosomatic and pervert symptoms. This patchwork evokes a borderline state. She acts sometimes like a narcissistic pervert.
\end{abstract}

Keywords: Incest, Incestual, Incestuous, Borderline State, Psychosis, Narcissistic Perversion

\section{Introduction}

Freud publishes in 1913 Totem and Taboo [11]. He is interested by the fear of incest in primitive societies. Two important bans in totemism, (kill the totem and have sex with a women of the totem) can be related to the oedipal interdictions (kill the father and have sex with the mother).

The dual ban of touching by the psychoanalyst Daniel Anzieu [1] in 1984 will show a new interest for incest.

In 1995, Incest and Incestual of French psychiatrist and psychoanalyst Paul Claude Racamier [18] makes a link between psychosis and incest. For Racamier, incest is a violence done to the body and the mind, with both a traumatism and a disqualification. Claude Balier [4] in 1996 considers incest as a sexual perversion.

Hélène Parat [14] will have a very complete approach of incest in a booklet published in 2004 and in Ban and taboo two years later [15].

In our days, revelations are more frequent and victims talk, silence is broken. Often kept secret in the families with denial, incest is unveiled and even exposed in movies. Christine Angot's book An Impossible Love [2] reveals that she has been her father's victim at age seven for many years, a recent movie [3] tells the story. The author of Little Tickles [6] brought up her book on stage and in a movie [7], playing her own role.

Incest is acted by an incestuous father or mother giving to their child the role of a sexual partner and considering him or her like a husband or spouse. There is no recognition of difference between generations, breaking the incest taboo. It is a violence done to a child who can't rebel against it. The parent should be there to protect the child, but instead he breaks into an immature sexuality with the consequences we know. Incest is a "mind killer", "a pleasure killer" says Racamier [18]. It damages the capacity to fantasize, not on the side of life but on the side of death!

What can we think about the incest between Anais Nin at age thirty and her father fifty-four years old? Anais seems to agree... Reading her Journal of Incest in the crude original version has been a great shock for me who recognizes the taboo of incest and I wanted to understand how such breaking could happen. 


\section{Method}

The material she brings in her diary can be treated like associations in a psychoanalysis. She has a lot of insight on her own. I worked with the Youth Journal 1914-1919 [12] and the Incest Journal 1932-1934 [13].

\subsection{The Incest}

In May 1933, she meets again with her father the pianist and composer Joachin Nin. She has not seen him since the age of eleven when he left his wife and children to rejoin his mistress, a rich heiress. Anais is married, without children, and her life is quite free with several lovers (like her father) the writer Henry Miller and her ex psychoanalyst Allendy.

This is what she writes in her diary:

"I found again my father, the God, only to discover that I don't need him anymore".

"When he comes to me, after having such influence on my childhood, I am a woman and I don't need any more a father or a god...He becomes again a man and a child in the same time".

"My father comes back when I have gotten rid of my cruel and blind instinct of punishing him".

"He isn't anymore the intellectual master I dreamed of (it is Henry now), the father I implored, the protector on which could count the child in me"

You can understand here the aggressiveness against her father who left her at age eleven and her desire to punish him and the way she considers him like a child. Balier [4] considers the incestuous father as a child with his children.

\subsubsection{An Incestual Father}

For Racamier [18] "incestual" means creating the climate of incest, "incestuous" committing incest.

When they meet again, Joaquin Nin acts like an incestual father before acting as an incestuous father. Since Anais sent a photo of her at age sixteen, he calls her his "fiancée". She looks very much physically like him. Her father has a Spanish origin, with a Catalan father and a Cuban mother. He is going to tell her his love affairs with his mistresses and his sexual life with Anais' mother: she is deeply shocked and is able to have a sane critical opinion. Then he relates an incestuous dream with her, his daughter, and tells her he is in love with her!!! He will behave like a lover until the consummate incest. Anais seems to be ambivalent, then agree. She feels desire and fear, and will resist to pleasure. I will spare you the crude details...

When a little girl of three or four says to her father: "I want to marry you", the father says: "This is not possible, you will marry your Prince Charming". Here no taboo of the incest. He treats his daughter like a narcissistic object.

How can we explain this incest accepted by an adult woman who seems to agree more or less? The father seems to have a loving feeling for his daughter, the result of a nonresolved Oedipus complex but we can imagine that there was a narcissistic seduction between his Cuban mother and himself. She must have treated him like a narcissistic object and gave him the place of his father... Joachin was the elder son. His father was a Spanish cavalry officer.

Joachin is a handsome man, a famous pianist, and a repentant seducer who did not give up narcissistic seduction with a double of himself. He has incestuous fantasies for his daughter, acts them in a dream and tells her. It is a crude dream without any elaboration. He behaves as an exciting father and manipulator, telling her about the intimate relations with his mistresses and his private sexual life with Anais's mother. Then he acts his incestuous fantasies, breaking the incest's taboo with no respect for the difference of generations. For Racamier [18]: "The incestual is a climate where blows the wind of incest".

When the sexual drives arise, incest occurs. The fathers' sexual desire appears in the dream and incest is going to happen. Narcissistic seduction is allied to incestuous manipulation. The father will violate his daughter's body intimacy. It is a breaking in and his pleasure exploded in her (the interdiction increased his pleasure).

The father does not feel guilty. The incest taboo does not exist for him. He wants to pursue this incestuous relation and is sorry not to be able to marry his daughter!!! Her father says: "When you were a child your body was so marvelous, had so perfect shapes. You had such a beautiful arched back. I loved to take pictures of you." This is not the way a father should look at his daughter. He looks at her like a lover. Her father was certainly an incestual father in her childhood.

\subsubsection{Consequences of Incest}

Anais feels guilty and responsible for this incest, just like the children victims of incest. She is ambivalent, feels desire and fear but also disgust. She has the impression "to be poisoned by this union".

Anais seems to remain this little girl of eleven, in love with her father, and feeling betrayed and abandoned by him for another woman, Marie-Louise his mistress. At eleven was she preferred to her mother, taking her mother's place, when the parents were fighting together? What is repeated in this family where incestual reigns?

Thanks to her diary, Anais can liberate herself of the traumatism of this incest. Anais had to promise her father the secret but she tells her lover Henry Miller and "confesses" to her former psychoanalyst Allendy.

Two weeks later, she feels intense heart beats and anxiety, thinks she is going to die (somatic and psychical symptoms) "My life stopped... I am restless... during the travel, I expected to die... I was crying... I can't stop dreaming... I lost my joy". She has anxiety dreams: "Henry leaves her and she runs in the forest sobbing". This is the punishment.

Anais Nin is an adult and her mind is already structured. She has a hysterical personality with seduction but her capacity to think, fantasize and dream are not touched. Her sexual life, arrived to maturity, looks like her father's: a spouse and lovers with an identification to him. She acts like a female Don Juan who was preferred by the father (Fain [6]) and her hypersexuality increases after the incest. The revelations on her parents' sexuality seem to have an impact. 
Anais thinks that her father is the best lover she ever had!!!

Anxiety and fears of death will disappear. When her possessive and jealous father wants her to quite Henry, she breaks with him and gives up the acting of her incestuous fantasies.

\subsection{Incest Equivalence: Acting in and Out}

\subsubsection{Acting in During Her Psychoanalysis with Allendy}

Listen to Anais in her Journal of Incest [13]: "The role I play to possess Allendy, I let him believe that analysis put an end to my masochistic devotion for Henry. I settled the story of this breaking with much care... My capacity to lie to Allendy the psychologist." This provides evidence for her desire of influence on Allendy, with much pleasure!!

The capacity to seduce, manipulate and lie evokes the narcissistic perversion described by Alberto Eiguer [5]. Acting in during a psychoanalysis is a breaking of the rules on both sides, the patient and the psychoanalyst. Anais transferred on her psychoanalyst Allendy her incestuous fantasies for her father and acted them. The incest with her father will repeat the acting in. Did the acting in make the incest easier or was-it premonitory?

The acting in during a psychoanalysis is an incest equivalence. The hysterical fantasy of seduction becomes a transfert acting says René Roussillon [19]. When the transfert is too intense, there is release of drives, release into acting (Jean-François Rabain [17]). The "acting in" happens during the session, the "acting out" after the session (André Barbier [5]). For Freud, this is an acting of the transfert with a shifting of affects on the person of the analyst. Janine Chasseguet-Smirgel [8] stresses the absence of psychical elaboration, of mental work (which can go with a normal intelligence).

\subsubsection{Acting Out with Otto Rank}

Anais writes on November the $7^{\text {th }} 1933$ : "I go to see him to confess myself... I am preparing a false comedy like with Allendy... but I was sincere as I am in front of my diary."

She wants to confess, like to a priest, because she feels guilty! Rank ask her to give up her diary, to break with everybody and to live alone!!! She understands: that she wrote her journal to replace her father, that unconsciously she imitated her father, her double and that she has been a child, a spouse, a lover but not a woman.

It was not a psychoanalysis but a psychoanalytic therapy which lasted only three months. We don't know how many sessions a week. Otto Rank is an Austrian psychoanalyst, considered as Freud's spiritual son, secretary of the psychoanalytic Society of Vienna. His book "The traumatism of birth" hasten the breaking up with Freud.

Anais admires Rank, she idealizes him like her father. She is fascinated by his fineness, liveliness, curiosity and spontaneity. It is an intellectual adventure, unique for her.

The acting will occur after the end of her psychotherapy. She misses Rank, writes to him and visits him. She dreams that she makes love with him. She invites him and his wife, with her husband. Then she will seduce him offering her lips and five days later they will make love.

They will go through a big passion. She finds him sensual, voluptuous, instinctive. She can in the same day have sexual intercourse with Henry in the morning, Rank in the afternoon and her husband in the evening!!! How can we understand her hypersexuality?

\subsection{A traumatic Separation at Eleven}

The incestual climate started certainly in her childhood. I was hoping to find in her Youth Journal 1914-1919 elements about her relationship with her father but unfortunately, they are very few. Anais don't talk about the past before her eleven years. Did she want to repress this past? But it is interesting to understand how her later personality will develop from what she experienced in New York after the separation and the uprooting in a country where her mother is going to rejoin several of her sisters.

We have to go back to the moment when the father leaves his family in Arcachon in May 1914. Anais starts her diary at the end of July just before the beginning of the war. After a stay in Barcelona with her paternal grandmother, Anais' mother and her three children sail to New York where aunts and cousins greet them at their arrival, a large, loving, lively and warm family.

Anais idealizes her father as "the greatest pianist in the world". She receives a letter from her dear father and hopes he will come for Christmas or for her birthday in February but she will be disappointed. She misses her father and often cries, take refuge in her diary and hides her sadness to the family. Does she want to keep secret this shameful and guilty love? She has been brought up in a catholic family. Concerning communion in church at Mass, she says: "During the Communion I feel rather kissing my father and receiving him than receiving God". Is this a fantasy of incorporation or an incestuous kiss? She learns that a dearer person retains him: Marie-Louise, a mistress. Anais will then dress in black. She feels his absence as a betrayal. She started then the mourning of her father's love and of her incestuous oedipal desires for him.

In New York, her mother will give her a maternal role, heavy to bear for an eleven years old girl, yet very mature (you can notice it in her journal). When she has to leave, she asks Anais to take care of her two younger brothers, do the cooking and the housework. In a biography, I read that her mother, the eldest of many siblings, was obliged to take care of the house and her brothers and sisters when her mother left the family to live in another house...

I make a link between Anais' somatic symptoms (pain in the legs and in the back) and this heavy maternal role. She then expresses the desire to be a man, to have no children and stay free to be able to write... We find there the way Anais will be adult. She will get married like her mother (her husband will protect her like her mother) with a very free life like her father. She will refuse motherhood and pregnancy, and will be maternal with her husband and lovers (like with her brothers).

In a repetitive way, during a year and a half she will 
complain in her diary about the lack of a father and her sadness, and express the desire to be a man and go fighting at war. Do we have to understand it as a regression to a reverse Oedipus complex, with identification to her father? Her daydreaming is going this way: "I see all the war's horror. I fight, and on the battle-field I see Father when he dies". This is how she expresses her death wishes toward her father. She is conscious now that she looks very much like him physically and also by a very independent and capricious personality, a steady, unwavering and severe temper.

Anais finds refuge in writing a diary, poems, short stories and reading. She is excellent in French essay. Writing is a need, a passion. Little by little, she will come out of her depression, go out with friends, visit her cousins, go to the movie, the theater, ride horse and have a life rich in friendship and leisure. She will take care of her look, get interested in boys and go to dances and balls. This proves the mourning process related to her father: she gives up her oedipal and incestuous desires and get interested in boys of her age and house holding with an identification to maternal substitutes. She says she is the "maid" of her mother who is in the same time mother and father, assuming her psychical bisexuality. Her mother works, receiving no financial support from the father.

\section{Result}

We can ask ourselves if the distance with her father and the good influence of the maternal family was not positive for Anais who was able to renounce to this excessive attachment to her father.

She gives away very little memories of her childhood. She suffered silently each time her father went around for his piano concerts. After an operation of appendicitis at nine, recovering in Arcachon, she was the witness of very sad fights between her parents. She remembers the lack of her father for her Communion.

How did her father behave with her when he was present? Did he behave as a seducer? Did he give the impression to prefer his daughter to his wife?

\section{Discussion}

Racamier [18] conceived of the idea of "incestual" for psychotic patients and psychotic symptoms without evident psychosis.

Anais seems to be very sensitive to object loss and separation, may be a borderline state but she is not psychotic. Her father seems to be psychotic without symptoms.

"The Oedipus bursts in an "open sky", a cry without flaw, in short without repression" says Racamier [18]. This is what we notice for the father when rejoining Anais, may be also for Anais after the separation. In borderline state, there is a flight ahead unto an Oedipus of coverage, defense against archaic anxieties. Incestual can be seen in psychotic families. Oedipus is the fantasy, and incest the act. The incestual is the equivalence of incest without symbolization while the incestuous has something to do with fantasy and symbolization.

The father's dream when they meet again is a crude, raw dream without symbolization. He dreams he has sex with his daughter and tells her. There is a lack of mentalization, fantasy and repression. Incestual takes the place of fantasy and prefigures the act. The fantasy has a link with the primal scene, while the incestual has nothing to do with it.

For the father it is common, normal to do sex with his daughter. $\mathrm{He}$ is ready to go on with this incestual relationship. I found in the Youth Journal a detail which can be linked with the incestual. Joaquinito, the youngest brother, ten years old, exposed himself naked and nobody could have him dress. He was six years old when the father left, and may be did he saw his father exposing himself naked?

The mother made few confidences to Anais when she received a letter from her father: "He would like to say a lot of things". And her mother answers: "To say bad things about your mother. You don't know your father's power when he writes and how he can convince everybody, even with lies".

Lies and manipulation are typical of narcissistic perversion.

Here some more confidences of her mother (who always tried to avoid depreciating their father): "Your father never loved his house, always with friends, strangers. Life was miserable because he was very brutal. He locked me in a room to be able to beat the children. He came home to criticize, to scold. One day in Arcachon, he wrote a letter and left... Do you remember those brutal scenes? No answer from Anais... Anais seems to have repressed that! The image of a brutal, sadistic father who beats his children appears, not only a seducer and a manipulator. For Claude Balier [4], he would be considered as a sexual pervert, but for me he seems to fluctuate between psychosis and narcissistic perversion [9].

\section{Conclusion}

This is an incest between a father and an adult daughter of thirty.

The father is an incestual and incestuous father who seduce and manipulate his daughter. The dream where he makes love with his daughter is crude and raw, with no elaboration, no mental work, no symbolization. The taboo of the incest, and the difference of generation does not exist for him. He has no respect for the body and intimacy of Anais and treats her like a narcissistic object. When he has sexual drives for his daughter, he acts them. He asks her to keep the incest secret. Fortunately, she does not and writes in her journal, tells her lover Henry Miller and "confesses" to her former psychoanalyst (and lover!) Allendy.

Anais seems to consent. She is ambivalent, she feels fear and desire, and also disgust. She feels guilty and responsible like would be a child. Is she again the little girl of eleven years in love with her father? We understand that Anais has been seduced and manipulated by her father in her childhood and that the painful and traumatic separation may have been 
beneficial for Anais and also the sane attitude of her mother's family.

The father oscillates between psychosis without symptoms and narcissistic perversion. He certainly created an incestual climate in her childhood and preferred her to her mother and put her in her place.

Anais, even if she is an adult of thirty years, can be considered as a victim of her father. Her hysterical personality, separation anxiety, psychosomatic and pervert symptoms shows a patchwork you can find in borderline state. She is good too at manipulating and lying to her psychoanalyst Allendy and her lovers and husband. Incest had an impact on her: heart palpitations, death anxiety, tears and loss of joy.

Incestual is a manifestation of perversity in some families where it is normal, banal but leads to destruction and havoc of the psychism. For the incestuous father, we are no more in the register of sexual perversion (sado-masochism, fetichism, voyeurism and exhibitionism), but of psychosis and narcissistic perversion.

\section{References}

[1] ANZIEU Daniel, The dual ban of touching, in Nouvelle Revue de Psychanalyse n²9, Gallimard, 1984.

[2] ANGOT Christine, An impossible love, Flammarion, 2015.

[3] ANGOT Christine, An impossible love, movie of Catherine Orsini, 2018.

[4] BALIER Claude, Psychoanalysis of violent sexual behaviours, Le Fil Rouge, PUF, 1996.

[5] BARBIER André, Acting, act and action in psychoanalysis, Acting in the psychoanalytic cure, Revue Française de Psychanalyse, 1984, 4.
[6] BESCOND Andrea, Little Tickles, play, 2018.

[7] BESCOND Andrea \& METAYER Eric, Little Tickles, movie, 2018.

[8] CHASSEGUET-SMIRGEL Janine, Acting out: a few remarks on the lack of psychical elaboration, Acting in the psychoanalytic cure, Revue Française de Psychanalyse, 19874.

[9] EIGUER Alberto, The Narcissistic Pervert and his Accomplice, Dunod, 2012.

[10] FAIN Michel \& BRUNSCHWEIG Denise, Eros and Anteros, Poche, Payot, 1971.

[11] FREUD Sigmund, (1912-1913), Totem and Taboo, Petite Bibliothèque Payot, 1976.

[12] NIN Anais, Youth Journal 1914-1919, Stock, 2010.

[13] NIN Anais, The Incest Journal. The unexpurgated Diary of Anais Nin 1932-1934, French translation 1995-1996, Stock, 2002.

[14] PARAT Hélène, Incest, Que sais-je, Payot, PUF, 2004.

[15] PARAT Hélène, Incest and its bans, Ban and taboo, Monographies and débats de psychanalyse, PUF, 2006.

[16] POTAMIANOU Anna, Exciting Hybris, Excitation, Revue Française de Psychanalyse, 2005, 1.

[17] RABAIN François, Acting in the cure, Acting in the psychoanalytic cure, Revue Française de Psychanalyse, 19874.

[18] RACAMIER Paul Claude, Incest and incestual, Dunod, 1995.

[19] ROUSSILLON René, Economy of the act and of the affect, Acting in the psychoanalytic cure, Revue Française de Psychanalyse, 1987-4. 